\title{
Carbon flow in coastal Louisiana
}

\author{
T. C. Feijtel, R. D. DeLaune \& W. H. Patrick, Jr \\ Laboratory for Wetland Soils and Sediments, Center for Wetland Resources, Louisiana State University, Baton Rouge, \\ Louisiana 70803-7511, USA
}

\begin{abstract}
Carbon flux data was synthesized to estimate carbon flow along a salinity gradient in Louisiana's Barataria Basin, a major Gulf Coast estuary (USA). Using a mass balance approach, we found an estuarine carbon surplus of 150 to $250 \mathrm{~g} \mathrm{~m}^{-2} \mathrm{yr}^{-1}$, which originated primarily in the tidal salt marsh. Carbon export from marshes to adjacent water bodies decreases with distance from the Gulf of Mexico. The Barataria Basin marshes function as important global carbon sinks within this export gradient. High community respiration, methane emission, and carbon accretion resulting from annual carbon fixation reduce carbon export from the northern part of the basin. Higher primary production, low community respiration, and low methane evolution make the southern part of the basin a source of aquatic carbon.
\end{abstract}

\section{INTRODUCTION}

Many studies and discussions address the export or outwelling of nutrients and organic carbon in Gulf and Atlantic coast estuaries (e.g. Haines 1976, Nixon 1980, Pomeroy \& Wiegert 1981, Day et al. 1982, Gosselink 1984, Teal 1984). Direct flux measurements, stable carbon isotope ratios, and marsh carbon budgets have been used to assess the carbon flow.

Recent work on carbon fluxes in fresh, brackish, and saline marshes along Louisiana's Gulf Coast (Hatton et al. 1983, Smith et al. 1983, DeLaune \& Smith 1984) provides a basis for increasing understanding of different interconnections between marsh habitats and adjacent water bodies. The mass balance approach previously used to calculate the carbon budget for the Barataria Basin (Day et al. 1982) was subject to high background noise. Using extrapolated data, Day et al. $(1977,1982)$ estimated wetland export from freshwater and brackish marshes. Numerous studies conducted during the past few years in Barataria Basin make it possible to approach the annual organic carbon budget from a source-sink point of view, considering the adjacent water bodies as transport media (e.g. Day et al. 1982, Smith et al. 1983, DeLaune \& Smith 1984, Stow et al. 1985).

Barataria Basin, the area for this study on major carbon fluxes, is an interdistributary Louisiana Gulf Coast estuarine basin $(400,000$ ha) with well-defined vegetative units bounded on the east by the Missis- sippi River and on the west by its most recently abandoned channel, Bayou Lafourche (Fig. 1). Several primary vegetative marsh units that generally corre-

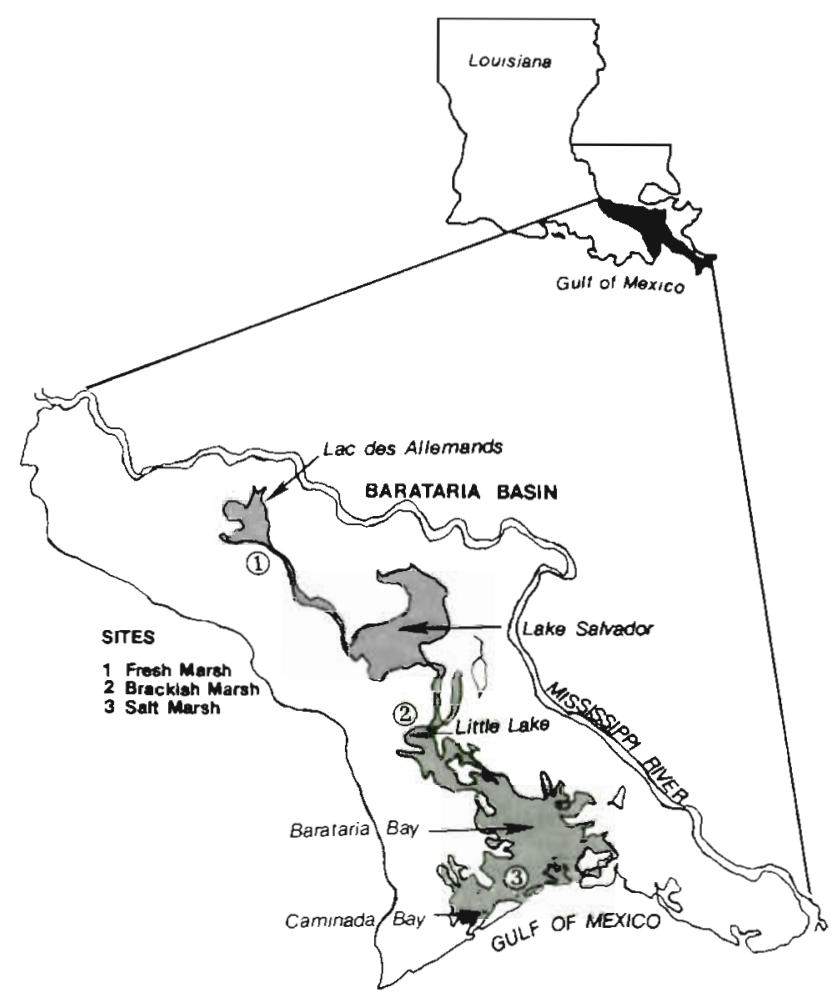

Fig. 1. Fresh, brackish and salt marshes in study area, Barataria Basin 
late with substrate type and salinity can be identified within the basin: saltwater marsh, brackish-intermediate marsh, and freshwater marsh (Bahr \& Hebrard 1976). Freshwater marsh (salinity $\leq 1 \%$ ) covers $19 \%$ of the basin and is characterized by Panicum hemitomon Schult, Eleocharis spp., and Sagittaria falcata Pursh. Brackish and intermediate marshes (1 to $10 \%$ ) together cover approximately $20 \%$ of the basin. The brackish marsh is vegetated largely by Spartina patens (Ait.) Muhl., Distichlis spicata (L.) Green, and small amounts of Spartina alterniflora Lois. The intermediate marsh is characterized by the dominance of $S$. patens and the absence of $S$. alterniflora. Saltwater marsh $(>10 \%)$ covers approximately $14 \%$ of the basin; $S$. alterniflora is the dominant vegetation.

Water bodies in the upper basin (Lac des Allemands) are characterized by high primary productivity, pronounced seasonality, and net heterotrophy (Day et al. 1982). The tidal range is $3.2 \mathrm{~cm}$ (Byrne et al. 1976), and waters are fresh. The lower basin has a tidal range of $12 \mathrm{~cm}$ (Marmer 1948) in the brackish area (Little Lake) and up to $30 \mathrm{~cm}$ in the bay (Day et al. 1982), with salinity up to $35 \%$. Autotrophic saline areas are less productive and lack consistent seasonality (Day et al. 1982).

\section{Marsh carbon flows \\ Primary production}

Researchers have reported aboveground production estimates for dominant marsh macrophytes in the Mississippi River deltaic plain over the past decade (Table 1). Aboveground production estimates varied from 1,410 to $2,895 \mathrm{~g}$ organic matter $\mathrm{m}^{-2} \mathrm{yr}^{-1}$ for saline habitats (Kirby \& Gosselink 1976, White et al. 1978). Brackish marshes exhibited the highest range of productivity, with values of 1,342 to $5,812 \mathrm{~g}$ organic matter $\mathrm{m}^{-2} \mathrm{yr}^{-1}$ (Hopkinson et al. 1978, White et al. 1978), and freshwater marshes produced between 1,500 and $1,700 \mathrm{~g}$ organic matter $\mathrm{m}^{-2} \mathrm{yr}^{-1}$ (Hopkinson et al. 1978, White et al. 1978, DeLaune \& Smith 1984, Sasser \& Gosselink 1984). (Spatial variability and the inherent difficulty of measuring net production make it difficult to determine true net primary production, which indicates the need for standardization of productivity techniques.) Hopkinson et al. (1978) pointed out that this higher production rate in brackish marshes is associated with the high biomass turnover rate of Spartina patens. Production estimates in Louisiana suggest that the turnover rates are a factor of 1.5 to 4.4 greater than peak standing crop (Kirby \& Gosselink 1976, Hopkinson et al. 1978, Sasser \& Gosselink 1984). Little data exists in belowground productivity estimates;
Table 1 Production of major marsh macrophytes in the Louisiana Mississippi River deltaic plain

\begin{tabular}{|c|c|c|c|c|}
\hline Species & $\begin{array}{c}\text { Peak } \\
\text { biomass } \\
\text { (g org. } \\
\text { matter } \\
m^{7} \text { ) }\end{array}$ & $\begin{array}{c}\text { Produc- } \\
\text { tivity } \\
\text { (gorg. } \\
\text { matter } \\
m^{-2} \text { yr }^{1} \text { ) }\end{array}$ & Method & Source \\
\hline \multirow[t]{5}{*}{ Spartina alterniflora } & 1018 & $\begin{array}{l}1410 \\
2645\end{array}$ & $\begin{array}{l}a \\
b\end{array}$ & (1) \\
\hline & 754 & 2658 & b & (2) \\
\hline & 1070 & 1527 & a & (3) \\
\hline & & 2895 & b & \\
\hline & 1080 & 2160 & c & \\
\hline \multirow[t]{7}{*}{ Spartina patens } & 1376 & 2000 & a & (2) \\
\hline & & 5812 & $b$ & \\
\hline & 1350 & 1342 & a & (3) \\
\hline & & 1428 & $\mathrm{~b}$ & \\
\hline & $1248-2466$ & $2605-4411$ & a & (4) \\
\hline & & $3056-3464$ & b & \\
\hline & 1100 & 1350 & c & (5) \\
\hline \multirow{2}{*}{ Panicum hemitomom } & 1160 & 1700 & d & $(6)$ \\
\hline & 1200 & 1500 & c & (5) \\
\hline \multicolumn{2}{|c|}{$\begin{array}{l}\text { a Smalley } 1958 \\
\text { b Wiegert \& Evans } 1964 \\
\text { c Barataria Basin study-site } \\
\quad \text { estimate } \\
\text { d Lomnincki et al. } 1968\end{array}$} & \multicolumn{3}{|c|}{$\begin{array}{l}\text { (1) Kirby \& Gosselink } 1976 \\
\text { (2) Hopkinson et al. } 1978 \\
\text { (3) White et al. } 1978 \\
\text { (4) Cramer \& Day } 1980 \\
\text { (5) DeLaune \& Smith } 1984 \\
\text { (6) Sasser \& Gosselink } 1984\end{array}$} \\
\hline
\end{tabular}

estimates of belowground biomass range from $25 \%$ to $90 \%$ for the main delta marsh plant species (Gosselink 1984).

\section{Gaseous carbon emission}

Smith et al. (1983) used diffusion chambers to obtain direct seasonal measurements of $\mathrm{CO}_{2}$ fluxes in salt, brackish, and freshwater marshes in Barataria Basin. They determined vertical flux density by monitoring the accumulation of $\mathrm{CO}_{2}$ in aluminum chambers placed over the water or sediment surfaces. Annual $\mathrm{CO}_{2}$ fluxes were 418,180 , and $618 \mathrm{~g} \mathrm{C} \mathrm{m}^{-2}$ from the saltwater, brackish, and freshwater marshes, respectively.

DeLaune et al. (1983) used diffusion chambers in a seasonal study of methane release in sediment from the saltwater, brackish, and freshwater marshes adjoining the basin and the adjacent open water areas, and found that methane emission is a significant process in the carbon and energy flow of the ecosystem. Methane emission is inversely related to salinity and sulfate concentrations; methane increases and salinity and sulfate decrease with increasing distance from the coast. The annual amounts of methane evolved were 4.3, 73, and $160 \mathrm{~g} \mathrm{C} \mathrm{m}^{-2}$ for the saltwater, brackish, and freshwater marshes, respectively. 


\section{Carbon sinks}

The role of these marshes as a major carbon sink has been determined from the carbon content of the sediment, vertical accretion rates, and the bulk density of the sediment (Smith et al. 1983). Accretion rates were calculated from depth in sediment of the horizon for 1963, the year of peak ${ }^{137} \mathrm{Cs}$ fallout (DeLaune et al. 1978). Net carbon accumulation was essentially the same in all 3 marshes: 183,296 , and $224 \mathrm{~g} \mathrm{C} \mathrm{m}^{-2} \mathrm{yr}^{-1}$ from the saltwater, brackish, and freshwater marshes, respectively. A large percentage of fixed carbon, immobilized in accretionary processes, remained on the marshes. Hatton et al. (1983) found similar carbon accumulation rates in these marshes.

\section{Aquatic carbon flows}

\section{Primary production}

Most water bodies adjacent to the Gulf of Mexico have been well described and primary production estimates well documented (e.g. Allen 1975, Hopkinson \& Day 1979, Day et al. 1982).

Day et al. (1982) divided the water portion of the basin into 2 regions based on temporal patterns, degree of eutrophy, and degree of heterotrophy. Water bodies in the upper basin are quite heterotrophic and eutrophic, but in the lower basin the ratio of production to respiration is close to one. The carbon fixation rate of $10 \mathrm{~g} \mathrm{C} \mathrm{m}^{-2} \mathrm{yr}^{-1}$ in Little Lake is low compared to the fixation rate of $73 \mathrm{~g} \mathrm{C} \mathrm{m}^{-2} \mathrm{yr}^{-1}$ in the freshwater lake and $123 \mathrm{~g} \mathrm{C} \mathrm{m}^{-2} \mathrm{yr}^{-1}$ in the saline (Hopkinson \& Day 1977). Only the saline lake showed a net community production $\left(20 \mathrm{~g} \mathrm{C} \mathrm{m}^{-2} \mathrm{yr}^{-1}\right)$; the freshwater lake consumed $169 \mathrm{~g} \mathrm{C} \mathrm{m}^{-2} \mathrm{yr}^{-1}$ and the brackish $44 \mathrm{~g} \mathrm{C}$ $\mathrm{m}^{-2} \mathrm{yr}^{-1}$ (Day et al. 1977, Day et al. 1982).

\section{Gaseous emission}

Water bodies adjacent to the major marsh types found in Barataria Basin evolved 103, 54, and $242 \mathrm{~g}$ $\mathrm{CO}_{2}-\mathrm{C} \mathrm{m}^{-2} \mathrm{yr}^{-1}$ to the atmosphere from saltwater, brackish, and freshwater lakes, respectively (Smith et al. 1983).

There was considerably less methane evolution from open water than from the marshes (DeLaune et al. 1983). The open-water environment adjacent to the marshes had a depth of approximately $1 \mathrm{~m}$, compared to an average depth of less than $10 \mathrm{~cm}$ of water overlying the marsh. This deeper water column can allow more methane (escaping from the bottom sediment) to be oxidized to carbon dioxide. Reported methane fluxes from open-water sites increase with distance from the coast (DeLaune et al. 1983). Annual methane emissions were $14 \mathrm{mg} \mathrm{C} \mathrm{m}^{-2}$ in fresh water, $4.8 \mathrm{mg}$ $\mathrm{C} \mathrm{m}^{-2}$ in brackish, and $1.3 \mathrm{mg} \mathrm{C} \mathrm{m}^{-2}$ in the salt water nearer the coast.

\section{Sinks}

Stow et al. (1985), using ${ }^{137} \mathrm{Cs}$ dating, found organic carbon sinks in a freshwater lake in the upper end of the basin (Lac des Allemands) of approximately $60 \mathrm{~g}$ $\mathrm{C} \mathrm{m}^{-2} \mathrm{yr}^{-1}$. Rates of carbon accumulation are similar in brackish and saline waters (Feijtel unpubl.).

\section{DISCUSSION}

The studies of carbon transformations in Barataria Basin make it possible to estimate carbon budgets for each part of the basin, based on major carbon flows (Table 2). Gaseous carbon emissions $\left(\mathrm{CO}_{2}\right.$ and $\left.\mathrm{CH}_{4}\right)$ and sinks formed by accretion and sedimentation pro-

Table 2. Mean organic carbon data used in mass balance of Barataria Basin ( $\mathrm{g} \mathrm{C} \mathrm{m}^{-2} \mathrm{yr}^{-1}$ )

\begin{tabular}{|c|c|c|c|}
\hline & Fresh & Brackish & Salt \\
\hline \multicolumn{4}{|l|}{ Marsh } \\
\hline Net primary production & $600^{\mathrm{a}}$ & $550^{a}$ & $860^{\circ}$ \\
\hline $\mathrm{CO}_{2}$ fixation & $700^{\mathrm{b}}$ & $400^{b}$ & - \\
\hline $\mathrm{CO}_{2}$ emission & $618^{\mathrm{c}}$ & $180^{\mathrm{c}}$ & $418^{c}$ \\
\hline $\mathrm{CH}_{4}$ production & $160^{d}$ & $73^{d}$ & $4.3^{\mathrm{d}}$ \\
\hline Sedim C accumulation & $224^{c . e}$ & $296^{c . e}$ & $183^{c, e}$ \\
\hline \multicolumn{4}{|l|}{ Open water } \\
\hline Net community production & $-600^{r}$ & $-44^{g}$ & $20^{\mathrm{g}}$ \\
\hline $\mathrm{CO}_{2}$ emission & $242^{c}$ & $54^{c}$ & $103^{c}$ \\
\hline $\mathrm{CH}_{4}$ production & $0.014^{\mathrm{d}}$ & $0.005^{d}$ & $0.001^{\mathrm{d}}$ \\
\hline Sedim. C accumulation & $60^{\mathrm{h}}$ & $60^{1}$ & $60^{\mathrm{i}}$ \\
\hline \multicolumn{4}{|c|}{$\begin{array}{l}\text { astimation based on study sites where flux determinations } \\
\text { were made (Table 1) }\end{array}$} \\
\hline \multirow{2}{*}{\multicolumn{4}{|c|}{$\begin{array}{l}\text { DeLaune \& Smith (1984): triplicate determinations, } 10 \text { times } \\
\text { during 1981-82 } \\
\text { c Smith et al. (1983): triplicate determinations, } 12 \text { times du- } \\
\text { ring 1980-81 }\end{array}$}} \\
\hline & & & \\
\hline \multicolumn{4}{|c|}{$\begin{array}{l}\text { DeLaune et al. (1983): triplicate determination in fresh and } \\
\text { salt marsh; duplicate in brackish marsh; } 13 \text { sampling dates } \\
\text { during } 1980-81\end{array}$} \\
\hline \multicolumn{4}{|c|}{$\begin{array}{l}\text { Hatton et al. (1983): }{ }^{137} \mathrm{Cs} \text { dating on } 10 \text { cores from stream- } \\
\text { side on lateral transects }\end{array}$} \\
\hline \multicolumn{4}{|c|}{ Day et al. (1977): monthly sampling during $1975-76$} \\
\hline \multicolumn{4}{|c|}{$\begin{array}{l}\text { Hopkinson \& Day (1979): monthly sampling from Dec } \\
\text { 1976-Feb } 1978\end{array}$} \\
\hline \multicolumn{4}{|c|}{ n Stow et al. $(1985):{ }^{137} \mathrm{C} 5$ dating on 5 cores } \\
\hline \multicolumn{4}{|c|}{ i Feijtel (unpubl.): duplicate determination 1984-85 } \\
\hline
\end{tabular}


cesses account for the major carbon outputs from the system.

The major inputs are $\mathrm{CO}_{2}$ fixation and aquatic $\mathrm{C}$ import from upper-basin drainage. Although we have no direct measurements of water movement, the general basin drainage direction is south to southeast. The aquatic carbon input from upland drainage was estimated to be approximately $165 \mathrm{~g} \mathrm{C} \mathrm{m}^{-2} \mathrm{yr}^{-1}$ in the freshwater marshes (Hopkinson \& Day 1979, Day et al. 1982). We incorporated aquatic net production, marsh/ water-body exchange, sedimentation, and drainage pattern into a mass-balance approach to estimate carbon transport to nearshore Gulf Coast areas (Fig. 2).

The volumetric approach taken by Happ et al. (1977) is based on monthly measurements of dissolved and particulate organic carbon. They applied average annual concentration gradient to a first-order mixing model to estimate the annual flux. Considering the magnitude of errors involved in the assumptions upon which the calculations were based, they reported an organic carbon export of 25 to $540 \mathrm{~g} \mathrm{C} \mathrm{m}^{-2}$ inshore water $\mathrm{yr}^{-1}$, with the most probable value around $150 \mathrm{~g} \mathrm{C} \mathrm{m}^{-2} \mathrm{yr}^{-1}$ (Happ et al. 1977).

A mass balance of average annual flux measurements approximates the net effects of global processes, such as net sedimentary carbon accumulation or net gaseous losses to the atmosphere. Atmospheric carbon dioxide fluxes decrease when the marsh is inundated. Gaseous evolution from the bottom sediment is very likely to be greater than the measured atmospheric evolution because inorganic carbon compounds form in the water column. The contribution of $\mathrm{CO}_{2}$ in flood-

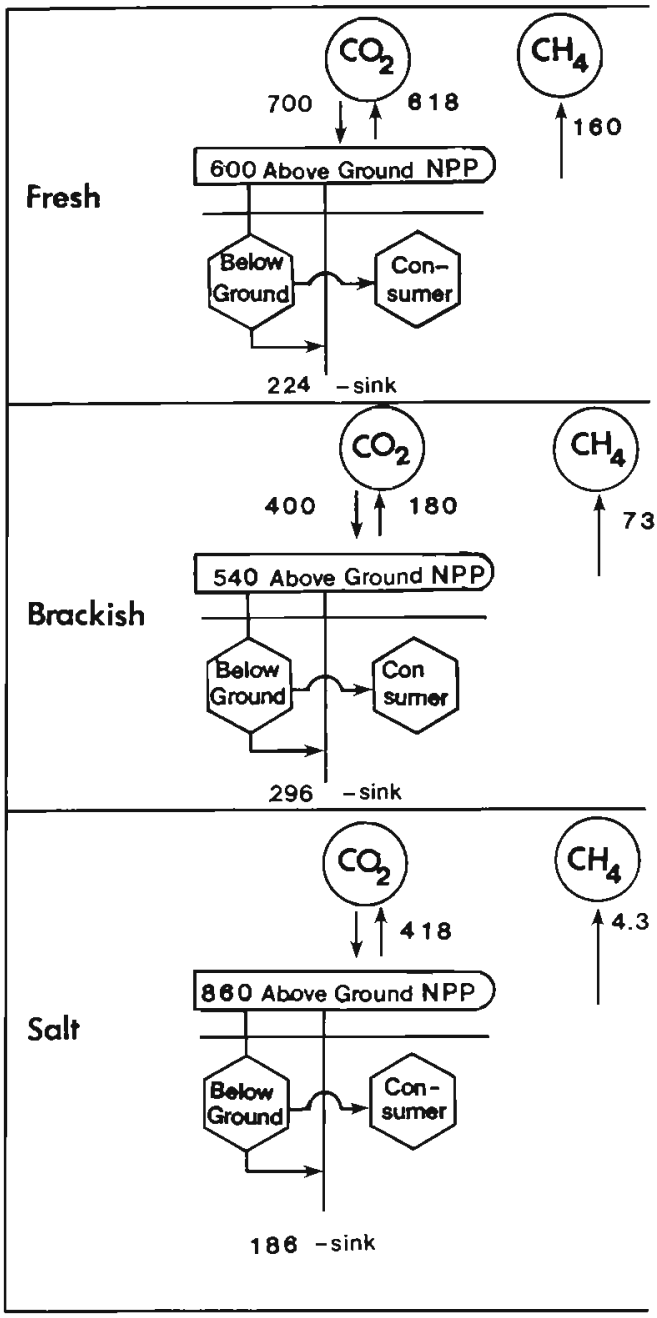

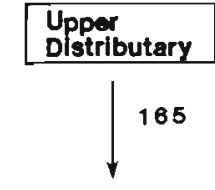
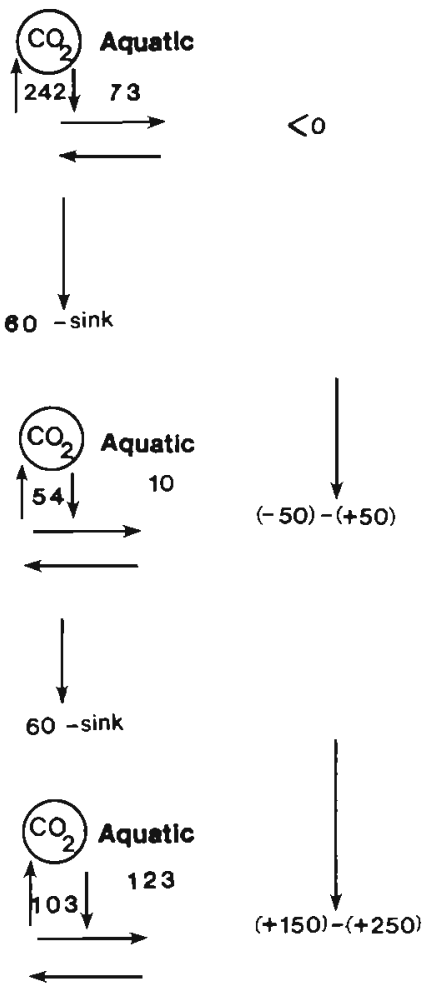

Fig. 2. Integrated carbon budget for Barataria Basin, showing flow pattern of carbon $\left(\mathrm{g} \mathrm{C} \mathrm{m}^{-2} \mathrm{yr}^{-1}\right)$ from freshwater marshes into brackish and saline 
waters is difficult to assess because it can be consumed by primary producers or leave the system in the tidewaters as bicarbonates and dissolved $\mathrm{CO}_{2}$. Gaseous carbon emissions may account for the major portion of the net gaseous loss from the marsh canopy.

Data obtained with ${ }^{137} \mathrm{Cs}$ dating indicates that marsh accretion processes fix carbon on the marshes as peat deposits or degrade and release it to the atmosphere as gaseous carbon. Because the carbon contribution apparently remains constant, we did not incorporate the previous year's contribution in calculating the carbon budget.

Belowground productivity of Gulf Coast marshes has not been estimated, and previously published carbon budgets were based on aboveground production studies and respiration of submerged marshes only (Day et al. 1973, Hopkinson \& Day 1977). Belowground biomass accounts for $25 \%$ of the total biomass of Spartina alterniflora, $57 \%$ of S. patens, and up to $90 \%$ of Panicum hemitomon (Gosselink 1984)

Productivity estimates made with $\mathrm{CO}_{2}$-fixation measurements include carbon translocation to belowground portions of the marsh (which equals gross primary production). Annual fixation rates were found to be $16 \%$ higher than clip-plot estimates of aboveground production in the freshwater marsh. Low turnover rates of belowground biomass in the freshwater marsh suggest a significantly lower productivity than in the aboveground portions. Belowground productivity estimates were not included in this mass balance. Burning of freshwater and brackish marshes for management purposes (Hoffpauer 1968) is thought to balance the majority of the ignored annual belowground input. We estimated that $25 \%$ to $35 \%$ is burned every year.

Annual fixation rates in the brackish marshes were found to be lower than the aboveground production estimates, indicating the importance of $\mathrm{CO}_{2}$ recycling and $\mathrm{CO}_{2}$ in floodwaters (Table 2). The lack of information on belowground production warrants future investigation for any refinement of the carbon budget presented.

Freshwater marshes were reported to import $165 \mathrm{~g} \mathrm{C}$ $\mathrm{m}^{-2} \mathrm{yr}^{-1}$ from the upper distributary (Hopkinson \& Day 1979), and fairly high aquatic carbon fixation rates probably balance the $\mathrm{C}$ deficit in these marshes. Comparative aquatic productivity studies in Barataria Basin showed that although the highest gross production is in Lac des Allemands $\left(1,231 \mathrm{~g} \mathrm{C} \mathrm{m}^{-2} \mathrm{yr}^{-1}\right)$, there was also a net community consumption of $-169 \mathrm{~g} \mathrm{C} \mathrm{m}^{-2}$ here (Day et al. 1977). This suggests an allochthonous input of nutrients and organic matter. This heterotrophic characteristic decreases as the tidal influence increases, with a net community production of $-44 \mathrm{~g} \mathrm{C} \mathrm{m}^{-2} \mathrm{yr}^{-1}$ in the brackish water bodies and $+20 \mathrm{~g} \mathrm{C} \mathrm{m}^{-2} \mathrm{yr}^{-1}$ in the saline. The freshwater marsh budget (Table 2) indicates a similar heterotrophy, and very little or no import is expected from the fresh water into the brackish wetlands.

The brackish marsh can be thought of as a transition zone on a hydraulic gradient where export or import occurs. The associated water body (Little Lake) is slightly heterotrophic and receives allochthonous carbon from surrounding marshland. Brackish $\mathrm{CO}_{2}$ fixation is apparently underestimated and carbon export probable. Soil $\mathrm{CO}_{2}$ flux accounts for the underestimation of atmospheric $\mathrm{CO}_{2}$ fixation. The contribution of soil $\mathrm{CO}_{2}$ to gross photosynthesis in various upland crops ranges between $10 \%$ and $40 \%$ (Monteith et al. 1964). Nixon (1980) reported that $40 \%$ of the plant biomass was produced from $\mathrm{CO}_{2}$ evolved from the surface of a Flax Pond marsh. Restricted diffusion in the grass canopy within the chambers and recycling of the evolved $\mathrm{CO}_{2}$ limits $\mathrm{CO}_{2}$ loss on the marsh surface. The integrated budget suggests a zero balance, but with net primary production and respiration correction factors, $C$ excess can be expected.

Southward transport and increased tidal range create $\mathrm{C}$ exchange in the saltwater marsh. The lowerbasin water bodies are either balanced or slightly autotrophic up to about $20 \mathrm{~g} \mathrm{C} \mathrm{m}^{-2} \mathrm{yr}^{-1}$ (Hopkinson \& Day 1979). Low methane evolution and low accretion make the saltwater marsh a source of aquatic carbon.

\section{CONCLUSIONS}

Marshes and bottom sediments of the water bodies within Barataria Basin function as an important global carbon sink, with marshes accumulating significantly more carbon than bottom sediments (Table 2). Freshwater, brackish, and saline marshes accumulate an equivalent of 37,54 and $21 \%$, respectively, of the aboveground productivity. Carbon accumulation in bottom sediments remains constant over the hydraulic gradient, $60 \mathrm{~g} \mathrm{~m}^{-2} \mathrm{yr}^{-1}$. The carbon contribution of the upper portion of Barataria Basin is minor, and the majority of the carbon export in the basin originates in the tidal saltwater marsh. The overall $\mathrm{C}$ budget for Barataria Basin indicates an excess of around 150 to $250 \mathrm{~g} \mathrm{C} \mathrm{m}^{-2} \mathrm{yr}^{-1}$. A large part of this 150 to $250 \mathrm{~g}$ $\mathrm{m}^{-2} \mathrm{yr}^{-1}$ is thought to be exported into the Gulf of Mexico.

Acknowledgement. This paper is a result of research supported by the National Science Foundation and the Louisiana Sea Grant Program, part of the National Sea Grant Program maintained by NOAA, United States Department of Commerce. 


\section{LITERATURE CITED}

Allen, R. L. (1975). Aquatic primary productivity in various marsh environments in Louisiana. M.S. thesis, Louisiana State Univ.

Bahr, L. M., Hebrard, J. J. (1976). Barataria Basin: biological characterization. Louisiana State Univ., Sea Grant Publ. T. 76-005, p. 1-144

Byme, P., Borengasser, M. J., Drew, G., Muller, R. A., Smith, B. L., Wax, C. L. (1976). Barataria Basin: hydrologic and climatologic processes. Louisiana State Univ., Center for Wetland Resources, Baton Rouge, Final Rep. to Louisiana State Planning Office, Baton Rouge, La

Cramer, G. W., Day, J. W., Jr. (1980). Productivity of the swamps and marshes surrounding Lake Pontchartrain, La In: Stone, J. H. (ed.) Environmental analyses of Lake Pontchartrain, Louisiana, its surrounding wetlands and selected land uses, Vol. 2. Coastal Ecology Laboratory Center for Wetland Resources, Louisiana State Univ., p $593-645$

Day, J. W., Jr., Butler, T. J., Conner, W. H. (1977). Productivity and export studies in a cypress swamp and lake system in Louisiana. In: Wiley, M. L. (ed.) Estuarine processes, Vol. II. Academic Press, New York, p. 255-269

Day, J. W., Jr., Hopkinson, C. S., Conner, W. H. (1982). An analysis of environmental factors regulating community metabolism and fisheries production in a Louisiana estuary. In: Kennedy, V. S. (ed.) Estuarine comparisons. Academic Press, New York, p. 121-136

Day, J. W., Jr., Smith, W. G., Wagner, P., Stowe, W. (1973). Community structure and carbon budget in a salt marsh and shallow bay estuarine system in Louisiana. Sea Grant Publ. 7Z-04. Louisiana State Univ., Center for Wetland Resources

DeLaune, R. D., Patrick, W H., Jr., Buresh, R. J. (1978). Sedimentation rates determined by ${ }^{137} \mathrm{Cs}$ dating in a rapidly accreting salt marsh. Nature, Lond. 275: 532-533

Delaune, R. D., Smith, C. J. (1984). The carbon cycle and the rate of vertical accumulation of peat in the Mississippi River Deltaic Plain. Southeast. Geol., 25: 61-68

Delaune, R. D., Smith, C. J., Patrick, W. H., Jr. (1983) Methane release from Gulf coast wetlands. Tellus 35: 8-15

Gosselink, J. G. (1984). The ecology of delta marshes of coastal Louisiana: a community profile. U.S. Fish Wildl. Serv., Office of Biological Services, Washington, D.C. FWS/OBS

Haines, E. B. (1976). Stable carbon isotope ratios in the biota, soils and tidal water of a Georgia salt marsh. Estuar. coast. mar. Sci. 4: 609-616

Happ, G., Gosselink, J. G., Day, J. W., Jr. (1977). The seasonal distribution of organic carbon in a Louisiana estuary. Estuar. coast. mar. Sci. 5: 695-705

Hatton, R. S., DeLaune, R. D., Patrick, W. H., Jr. (1983). Sedimentation, accretion and subsidence in marshes of Barataria Basin, Louisiana. Limnol. Oceanogr. 28 : 494-502

Hoffpauer, C. M. (1968). Burning for coastal marsh management. In: Newsom, J. D. (ed.) Proceedings of the marsh and estuary management symposium. Louisiana State Univ., Div. of Continuing Educ. p. 134-139

Hopkinson, C. S., Day, J. W., Jr. (1977). A model of the Barataria Bay salt marsh ecosystem. In: Hall, C. A. S., Day, J. W., Jr. (ed.) Ecosystem modeling in theory and practice. John Wiley and Sons, New York, p. 235-265

Hopkinson, C. S., Day, J. W., Jr. (1979). Aquatic productivity and water quality at the upland-estuary interface in Barataria Basin, Louisiana. In: Livingston, R. (ed.) Ecological processes in coastal and marine systems. Plenum Press, New York, p. 291-314

Hopkinson, C. S., Gosselink, J. G., Parrondo, R. T (1978) Aboveground production of seven marsh plant species in coastal Louisiana. Ecology 59: 760-769

Kirby, C. J., Gosselink, J. G. (1976). Primary production in a Louisiana Gulf coast Spartina alterniflora marsh. Ecology 57: 1052-1059

Lomnincki, A., Bandola, E., Jankowaska, J. (1968). Modification of the Wiegert-Evans method for estimation of net primary production. Ecology 49: 147-149

Marmer, H. A. (1948). The currents in Barataria Bay. Texas A \& M Research Foundation, College Station, Texas, Project 9, p. $1-30$

Monteith, J. L., Szeicz G., Yabuki, K. (1964). Crop photosynthesis and the flux of carbon dioxide below the canopy. J. Appl. Ecol. 1: 321-337

Nixon, S. W. (1980). Between coastal marshes and coastal waters - a review of twenty years of speculation and research on the role of saltmarshes in estuarine productivity and water chemistry. In: Hamilton, P., MacDonald, K. B. (ed.) Estuarine and wetland processes. Plenum, New York, p. 438-525

Pomeroy, L. R., Wiegert, R. G. (ed.) (1981). The ecology of a salt marsh. Springer-Verlag, New York, p. 1-271

Sasser, C. E., Gosselink, J. G. (1984). Vegetation and primary production in a floating freshwater marsh in Louisiana. Aquat. Bot. 20: 245-255

Smalley, A. E. (1958). The role of two invertebrate populations, Littorina irrorata and Orchelium fidicenium in the energy flow of a salt marsh ecosystem. Doctoral thesis. Univ. of Georgia, Athens, Georgia

Smith, C. J., Delaune, R. D., Patrick, W. H., Jr. (1983). Carbon dioxide emission and carbon accumulation in coastal wetlands. Estuar. coast. Shelf Sci. 17: 21-29

Stow, C. A., DeLaune, R. D., Patrick, W. H., Jr. (1985). Nutrient fluxes in a eutrophic coastal Louisiana freshwater lake. Environ. Mgmt., in press

Teal, J. M. (1984). Tidal salt marshes of eastern North America: the ecology of the low salt marsh. U.S. Fish Wildl. Serv., Office of Biological Services, Washington, D.C. FWS/OBS

White, D. A., Weiss, T. E., Trapani, J. M., Thien, L. B. (1978) Productivity and decomposition of the dominant salt marsh plants in Louisiana. Ecology 59: 751-759

Wiegert, R. G., Evans, F. C. (1964). Primary production and the disappearance of dead vegetation in an old field in southwestern Michigan. Ecology 45: 49--63 